\title{
Article
}

\section{The effect of surface type, collection and extraction methods on touch DNA}

\author{
Alketbi, Salem Khalifa and Goodwin, William H \\ Available at http://clok.uclan.ac.uk/36279/ \\ Alketbi, Salem Khalifa ORCID: 0000-0002-7773-3953 and Goodwin, William H \\ ORCID: 0000-0002-3632-3552 (2019) The effect of surface type, collection \\ and extraction methods on touch DNA. Forensic Science International: \\ Genetics Supplement Series, 7 (1). pp. 704-706. ISSN 1875-1768
}

It is advisable to refer to the publisher's version if you intend to cite from the work. http://dx.doi.org/10.1016/j.fsigss.2019.10.145

For more information about UCLan's research in this area go to http://www.uclan.ac.uk/researchgroups/ and search for < name of research Group>.

For information about Research generally at UCLan please go to http://www.uclan.ac.uk/research/

All outputs in CLoK are protected by Intellectual Property Rights law, including Copyright law. Copyright, IPR and Moral Rights for the works on this site are retained by the individual authors and/or other copyright owners. Terms and conditions for use of this material are defined in the policies page.

\section{CLoK}

Central Lancashire online Knowledge www.clok.uclan.ac.uk

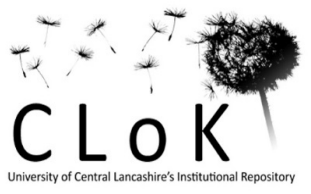




\section{Journal Pre-proof}

The effect of surface type, collection and extraction methods on Touch DNA

Salem K. Alketbi, W. Goodwin

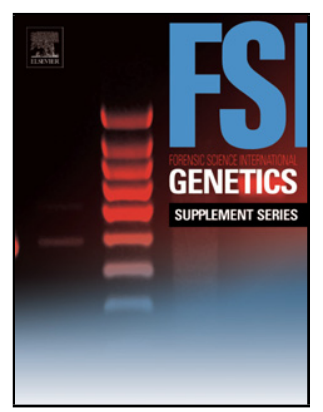

PII:

S1875-1768(19)30198-2

DOI:

https://doi.org/10.1016/j.fsigss.2019.10.145

Reference:

FSIGSS 1778

To appear in:

Forensic Science International: Genetics Supplement Series

Received Date:

5 September 2019

Revised Date:

9 October 2019

Accepted Date:

11 October 2019

Please cite this article as: Alketbi SK, Goodwin W, The effect of surface type, collection and extraction methods on Touch DNA, Forensic Science International: Genetics Supplement Series (2019), doi: https://doi.org/10.1016/j.fsigss.2019.10.145

This is a PDF file of an article that has undergone enhancements after acceptance, such as the addition of a cover page and metadata, and formatting for readability, but it is not yet the definitive version of record. This version will undergo additional copyediting, typesetting and review before it is published in its final form, but we are providing this version to give early visibility of the article. Please note that, during the production process, errors may be discovered which could affect the content, and all legal disclaimers that apply to the journal pertain.

(c) 2019 Published by Elsevier. 


\title{
The effect of surface type, collection and extraction methods on Touch DNA
}

\author{
Salem K Alketbi ${ }^{1,2^{*}}$, Dr W. Goodwin ${ }^{1}$
}

${ }^{1}$ University of Central Lancashire, Preston, UK

${ }^{2}$ General Department of Forensic Science and Criminology, Dubai Police, Dubai, UAE

*Tel: 00447774141205; E-mail: alkitbe.11@hotmail.com

\begin{abstract}
There are different variables that affect the success of Touch DNA recovery, including surface type, the collection method used and extraction techniques. This experiment investigated how a range of porous and non-porous surfaces, different DNA collection (cotton swab, nylon flocked swab and SceneSafe Fast ${ }^{\mathrm{TM}}$ minitape) and extraction methods (PrepFiler Express BTA ${ }^{\mathrm{TM}}$ and QIAamp ${ }^{\circledR}$ DNA Investigator) affected touch DNA recovery.
\end{abstract}

\section{Introduction}

Different variables that affect the success of obtaining a substantial quality DNA profile from Touch DNA, including shedder status, surface type, and pressure of contact, as well as the method used for DNA collection and extraction [1]. Although previous studies have investigated the effectiveness of different methods used for DNA recovery, there are some deficiencies of published information regarding touch DNA recovery [2]. The duration, over which the deposit on the surface and the area over which the touch occurs is important, as it helps to evaluate the effectiveness of sampling touch DNA [3]. There is a need to incorporate recovery and extraction efficiencies in the interpretation of trace DNA from various of surfaces [4], and the following study sought to investigate the effect of surface type, DNA collection and extraction methods on Touch DNA recovery.

\section{Materials and methods}

\subsection{Experimental set}

A selection of six surfaces (stainless steel, smooth non-porous; glass, smooth non-porous; textured wood, rough porous; banana skin, smooth porous; copier paper, smooth porous and textured plastic, rough nonporous) were chosen to replicate common items encountered in crime scenes. All non-porous surfaces were cleaned with $2 \%$ virkon (viricidal disinfectant) and ultraviolet radiation (UV) for 15 min; porous surfaces were irradiated using UV light for $25 \mathrm{~min}$.

\subsection{Deposition}


Two participants were asked to wash their hands with antibacterial soap and refrain from undertaking any activity for $10 \mathrm{~min}$. Then, they were asked to charge the fingers of both hands with eccrine sweat by touching behind their ears or forehead to load them with DNA. The participants were then asked to touch the surfaces using the index, middle, and ring fingers of both hands separately for deposition by applying medium pressure on a $5 \times 7 \mathrm{~cm}$ area of the surface for $1 \mathrm{~min}$. The same procedure was repeated on all surfaces for equal deposition. Each participant deposited on separate six surfaces six times to make a total of 72 samples (two replicates for each surfaces), then one participant was asked to do further depositions on glass $(n=18)$ and copier paper $(n=18)$ (three replicates for each surfaces) to test the variables. All the depositions were done at room temperature.

\subsection{DNA recovery and extraction}

Three different methods were used to recover the touch DNA, Copan cotton swab (150C) (CS), Copan nylon flocked swab (4N6 FLOQSwabs ${ }^{\circledR}$ ) (NS), and SceneSafe Fast ${ }^{\mathrm{TM}}$ minitape (K545) (MT). Before collection, $100 \mu \mathrm{L}$ of sterile distilled water was applied to moisten CS using a plastic spray bottle technique (developed in Dubai police forensic DNA lab; each single spray contains approximately $50 \mu \mathrm{L}$ ). For NS, 30 $\mu \mathrm{L}$ of sterile distilled water was applied to moisten the swab using a pipette as recommended by the manufacturer. No water was added to the MT, but to increase the amount of touch DNA collected, each minitape was applied 16 times to the area [5].

Touch DNA was recovered from the surfaces $30 \mathrm{~min}$ after deposition and extracted immediately. Samples deposited by the two participants $(n=72)$ were extracted by PrepFiler Express BTA ${ }^{\text {TM }}$ kit (Thermo Fisher Scientific) (EXT 1) using an AutoMate Express Forensic DNA Extraction System according to the manufacturer's recommendations and manually using the QIAamp ${ }^{\circledR}$ DNA Investigator Kit (Qiagen) (EXT 2) as per the manufacturers' protocol. However, with EXT 2 nylon swabs were extracted using NAOBasket ${ }^{\mathrm{TM}}$ as recommended by Copan to increase the DNA yield.

For the extra deposition made by participants one for glass $(n=18)$ and copier paper $(n=18)$ the same extraction techniques were used, but for EXT $1460 \mu \mathrm{L}$ of lysis buffer was used instead of $230 \mu \mathrm{L}$. For all extracted samples, full swab heads were used and the lower sticky part of the minitape, with a final extracted sample elution of $50 \mu \mathrm{L}$.

\subsection{DNA quantification, amplification and analysis}

Extracted samples were quantified using the Quantifiler ${ }^{\circledR}$ Human DNA Quantification Kit, QuantStudio 5 Real-Time PCR (qPCR) and HID Real-Time PCR analysis software v1.3 according to the manufacturer's instructions (Thermo Fisher Scientific). Amplification were performed using the GlobalFiler ${ }^{\mathrm{TM}}$ PCR amplification Kit (Thermo Fisher Scientific), following the 30 cycles protocol. The data were analysed using GeneMapper ${ }^{\circledR}$ ID-X Software Version 1.2 (Thermo Fisher Scientific). Statistical analysis on the tested variables was performed with RStudio using factorial analysis of variance (ANOVA). In ANOVA the p-value is derived from the F-distribution which is different for every pair of degree of freedom (df) values ( $F$ value =variance of the variables means (Mean Square Between) / mean of the within variables variances (Mean Squared Error))

Blanks were taken from surfaces after cleaning, and negative controls for the collection and extraction methods, all of which were DNA-free when quantified. Random samples from the surfaces were amplified to evaluate the quality of samples collected; the amplified samples produced full DNA profiles without any sign of mixtures or contamination.

\section{Results and discussion}


The amount of DNA collected from the selected six surfaces $(n=72)$ was significantly affected by the type of surface $\left(F_{5,36}=3.469, p<0.05\right)$, and the extraction methods $\left(F_{1,36}=72.286, p<0.05\right)$. The highest amount of DNA was recovered from glass surfaces, and the least amount of from copier paper surfaces with both extraction methods. Samples extracted by EXT 2 were higher in DNA than samples extracted by EXT 1 when manufacturer's protocols were followed (Figure 1). That was not the case when $460 \mu \mathrm{L}$ of lysis buffer were used with EXT 1 instead of $230 \mu \mathrm{L}$ for the extra samples on glass $\left(F_{1,12}=1.05, p=0.33\right)$ and copier paper $\left(F_{1,12}=4.74, p=0.05\right)$ (Figure 2 ).

By analysing the extra samples collected from glass and copier paper individually (Figure 2), the amount of DNA collected from glass $(n=18)$ was significantly affected by collection type $\left(F_{2,12}=22.36, p<0.05\right)$, the interaction between collection type and extraction method $\left(F_{2,12}=13.70, p<0.05\right)$. There was not a big difference of DNA extracted by both extraction methods when samples were collected by CS and NS.

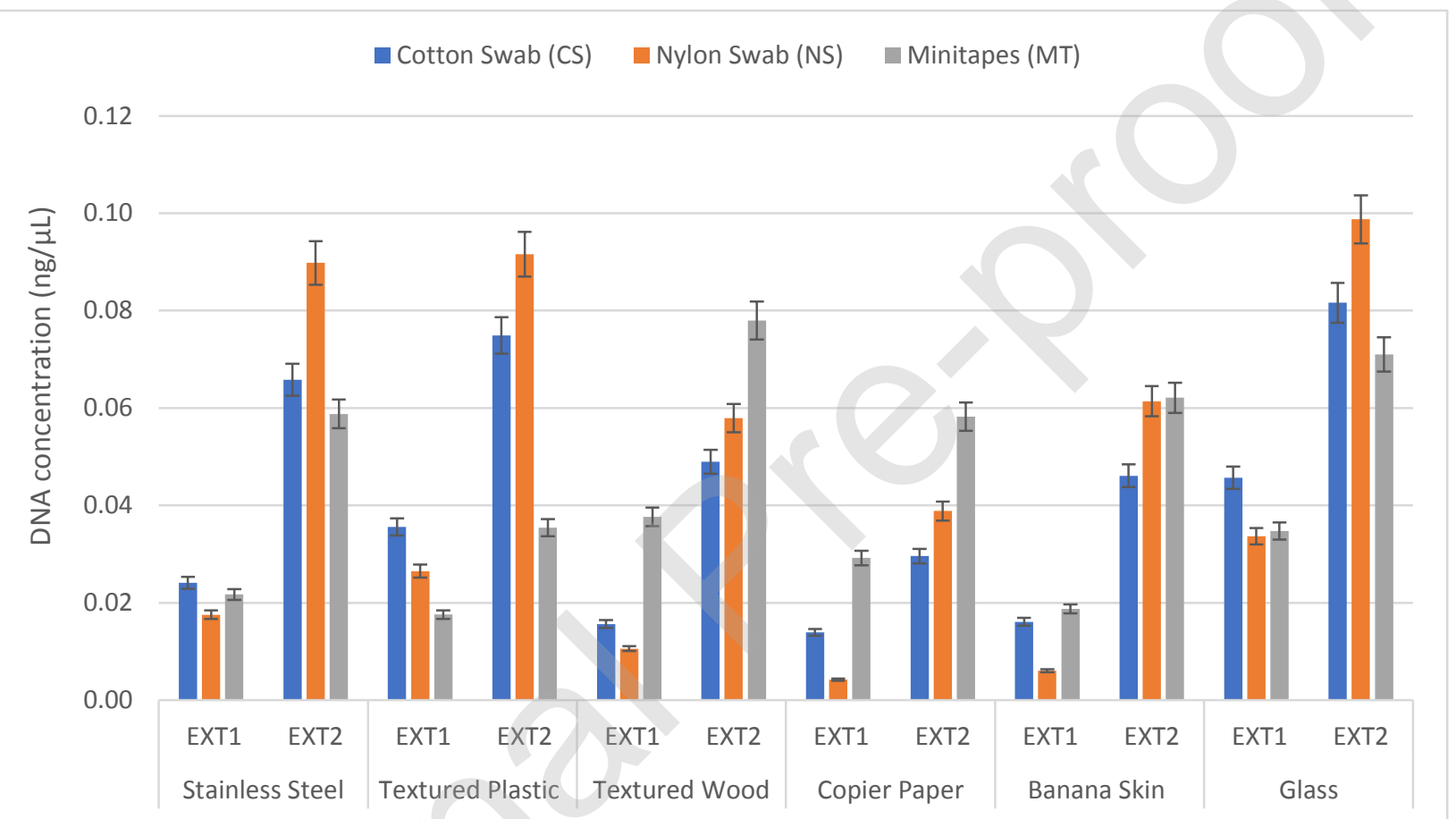

In contrary, some collected DNA was not efficiently extracted by EXT 2 when samples were collected by MT (Mean $0.03 \mathrm{ng} / \mu \mathrm{L}$ ), when compared to samples collected by MT and extracted by EXT 1 (Mean: 0.06 $\mathrm{ng} / \mu \mathrm{L})$. Furthermore, the amount of DNA collected from copier paper $(\mathrm{n}=18)$ was significantly affected by collection type $\left(F_{2,12}=9.25, p<0.05\right)$ and the interaction between collection type and extraction method $\left(F_{2,12}=7.46, p<0.05\right)$. MT was the most suitable collection type for copier paper and EXT 1 the most efficient extraction method with MT (mean: $0.04 \mathrm{ng} / \mu \mathrm{L}$ ) compared to EXT 2 (mean: $0.02 \mathrm{ng} / \mu \mathrm{L}$ ).

Figure 1. Mean of DNA recovered from the six surfaces $(n=72)$ using three collection methods and extracted using two extraction methods, PrepFiler Express BTA ${ }^{\mathrm{TM}}$ kit (EXT 1) and QIAamp ${ }^{\circledR}$ DNA Investigator Kit (EXT 2). CS performed better with EX1 and NS performed better with EXT 2 when used on non-porous surfaces. MT performed better when used on porous surfaces regardless the effect of extraction. Error bars represent $95 \%$ confidence intervals. 

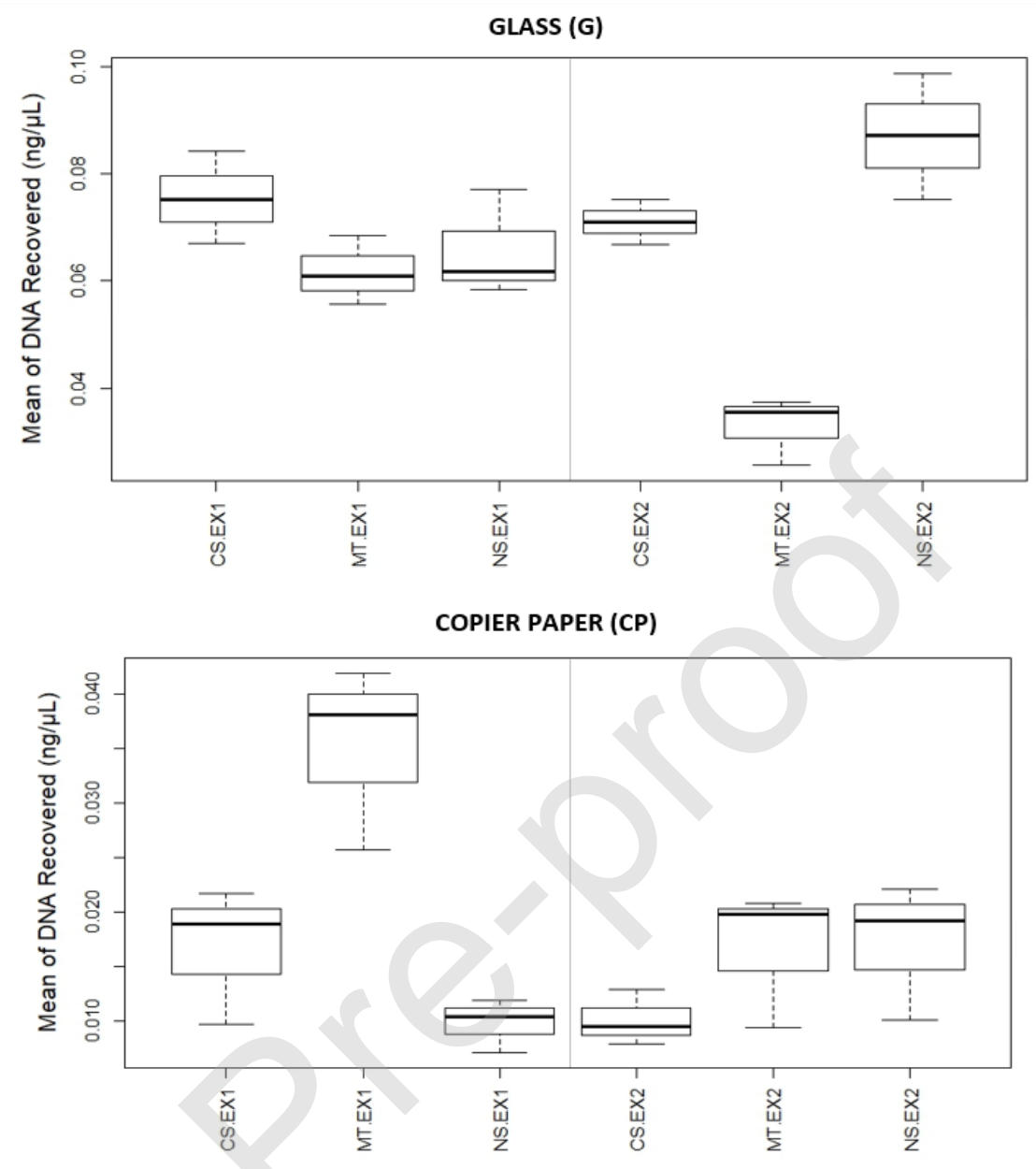

Figure 2 - The mean of DNA recovered from glass $(n=18)$ and copier paper $(n=18)$. Collected by cotton swab (CS), nylon swab (NS) and minitapes (MT), then extracted by two extraction methods [PrepFiler Express BTA ${ }^{\mathrm{TM}}$ kit (EX1) and QIAamp ${ }^{\circledR}$ DNA Investigator Kit (EX2)]. Error bars represent standard Error.

\section{Conclusion}

In conclusion, surfaces retain Touch DNA differently and it is important to consider the most appropriate collection method for different type of surfaces. From the experimental findings, it is recommended to use cotton swabs or nylon swabs for non-porous surfaces such as glass and textured plastic, whereas the use of tapes is better for porous surfaces such as paper or wood. Moreover, for optimal recovery of DNA different types of collection method require different extraction processes. Different extraction methods, automated or manual, have different requirements, with the specimen size in combination with the amount of lysis buffer influencing the maximum DNA yield. Based on these finding, it is recommended to use different protocols to collect and process Touch DNA from various of surfaces. 


\section{Conflict of interest}

None.

\section{Acknowledgements}

This study was approved by the General Department of Forensic Science and Criminology in Dubai Police and Ethical approval was granted by the School of Forensic and Applied Sciences, and the University of Central Lancashire's Research Ethics Committee (ref. no. STEMH 912). Many thanks to COPAN DIAGNOSTICS INC. for supporting this experiment with free swabs, and to ThermoFisher Scientific ${ }^{\mathrm{TM}}$ for discounts on their products. 


\section{References}

[1] S.K. Alketbi, The Affecting Factors of Touch DNA. Journal of Forensic Research. 9(3) (2018) 424.

[2] R.J. Brownlow, K.E. Dagnall, C.E. Ames, A comparison of DNA collection and retrieval from two swab types (cotton and nylon flocked swab) when processed using three QIAGEN extraction methods. Journal of Forensic Sciences. 57 (3) (2012) 713-717.

[3] S.H. Tobias, G.S. Jacques, R.M. Morgan, et al., The effect of pressure on DNA deposition by touch. Forensic Science International: Genetics Supplement Series. 6 (C) (2017), 12-14.

[4] D. Taylor, A. Biedermann, L. Samie, et al., Helping to distinguish primary from secondary transfer events for trace DNA. Forensic Science International: Genetics. 28 (2017) 155-177.

[5] T.J. Verdon, R.J. Mitchell, R.A. van Oorschot, Evaluation of tapelifting as a collection method for touch DNA. Forensic Science International: Genetics. 8(1) (2014) 179-186. 